ALICJA ŻYWCZOK

Wydział Pedagogiki i Psychologii

Uniwersytet Śląski

Katowice
Forum Pedagogiczne $2018 / 1$

Wpłynęło: 26.10.2017

Zatwierdzono do druku: 31.03 .2018 DOI: 10.21697/fp.2018.1.08

\title{
TROSKA, ZATROSKANIE, TROSKLIWOŚĆ - NIESPECYFICZNE PRZEDMIOTY BADAŃ PEDAGOGIKI OGÓLNEJ
}

\begin{abstract}
Streszczenie: Odwołując się do dotychczasowego stanu wied zy z zakresu pedagogiki i nauk pokrewnych (zwłaszcza filozofii, psychologii, medycyny, politologii, teologii), w treści artykułu autorka zaakcentowała znaczenie interdyscyplinarnej kategorii troski (oraz terminów zbliżonych semantycznie, takich jak: „zatroskanie”, „troszczenie się”, „zatroszczenie się”, „troskliwość”) w rozwoju subdyscypliny pedagogicznej - pedagogiki ogólnej. Oprócz wyjaśnień leksykalnych prowadzących do wykazania różnic między wskazanymi terminami, przeanalizowała naukowe ujęcie troski (jako m.in.: normy i powinności moralnej, relacji społecznej, dyspozycji, postawy) oraz powiązania troski z innymi wartościami moralnymi. Autorka ukazała jednocześnie uwarunkowania procesu wychowania człowieka troskliwego oraz etapy interioryzacji analizowanej wartości. Posłużenie się metodami hermeneutycznymi oraz analizą logiczną i argumentacją w badaniu problematyki troski wydaje się uzasadnione, biorąc pod uwagę konieczność jej pogłębionego poznania.
\end{abstract}

Słowa kluczowe: troska, zatroskanie, troszczenie się, zatroszczenie się, powinność, postawa opiekuńcza, proces wychowania, przedmiot badań.

\section{Wprowadzenie}

Jednym z zadań reprezentantów pedagogiki ogólnej jest rozbudowa aparatury pojęciowej za pośrednictwem odkrywania istotnych w tej subdyscyplinie kategorii pojęciowych, które pozyskiwane są z innych nauk, dziedzin kultury, języka potocznego oraz doświadczenia praktyków. Chociaż treść pojęcia troski sugeruje, iż stanowi ona podstawowy termin takich subdyscyplin pedagogicznych, jak pedagogika opiekuńcza, pedagogika socjalna, pedagogika rodziny, pedagogika społeczna, pedagogika specjalna (w której nadal obowiązuje termin „człowiek specjalnej troski”), andragogika (por. Szmaus-Jackowska 2011), w dorobku naukowym wyliczonych subdyscyplin daje się dostrzec zaledwie próby intencjonalnego nawiązania 
do kategorii troski. Znacznie częściej można w nich odnaleźć inne terminy bliskoznaczne: „opieka”, „pomoc”, „wsparcie”, „wspomaganie”. Odniesienie troski do wielu podmiotów wychowujących (np. rodziców, wychowawców, pedagogów, opiekunów, nauczycieli, animatorów, pracowników socjalnych, asystentów rodzin, kuratorów sądowych i społecznych), podmiotów wychowywanych (np. wychowanków, uczniów, podopiecznych) oraz różnorodnych środowisk, placówek i instytucji z pewnością uzupełniłoby stan wiedzy pedagogicznej w tym zakresie.

Problematyka troski nie została w pedagogice wystarczająco zgłębiona badawczo: opisana i wyjaśniona. W związku z tym eksploracji wymaga troska ujmowana zarówno jako kategoria teoretyczna (tak rozpatrują ją reprezentanci pedagogiki ogólnej i teorii wychowania), jak i praktyczna. Niezwykle rzadkie badanie troski czyni ją kategorią atrakcyjną również dla naukowców-pedagogów ogólnych i teoretyków wychowania (zwłaszcza moralnego, społecznego i obywatelskiego) oraz niespecyficznym, więc oryginalnym przedmiotem badań w tych subdyscyplinach. Posłużenie się metodami hermeneutycznymi w badaniu problematyki troski ${ }^{1}$ wydaje się uzasadnione, biorąc pod uwagę konieczność jej pogłębionego poznania. Skorzystam również z metod filozofii analitycznej - analizy logicznej i argumentacji.

Odwołując się do dotychczasowych osiągnięć z zakresu pedagogiki i nauk pokrewnych (zwłaszcza filozofii, psychologii, medycyny, politologii, teologii), w treści niniejszego artykułu zaakcentuję znaczenie interdyscyplinarnej kategorii troski (oraz terminów zbliżonych semantycznie, takich jak: „zatroskanie”, „troszczenie się”, „zatroszczenie się”, „troskliwość”) w rozwoju pedagogiki ogólnej. Oprócz wyjaśnień leksykalnych, prowadzących do wykazania różnic między wskazanymi terminami, przeanalizuję naukowe ujęcie troski (jako m.in.: normy i powinności moralnej, relacji społecznej, dyspozycji, postawy) oraz powiązania troski z innymi wartościami moralnymi. Ukażę jednocześnie uwarunkowania procesu wychowania człowieka troskliwego oraz etapy interioryzacji analizowanej wartości.

\section{Próba uargumentowania powinności troski o drugiego człowieka}

„Troska jest uniwersalną kategorią etyczną i pragmatyczną, należy bowiem do pola pracy humanitarnej w ogóle, niezależnie od szczegółowych odniesień narodowych, kulturowych, religijnych, politycznych. Wiąże się z problematyką istoty i powołania człowieka oraz określonym systemem wartości. Troska o kogoś lub o coś chroni przed zagrożeniami i przyczynia się do rozwoju określonych dóbr, niezależnie od tego, czy jest podejmowana przez osoby, czy system formalnoprawny. Kieruje człowieka w stronę tego, do czego dąży, czego pragnie i poszukuje, jest więc źródłem dynamiki ludzkiego działania oraz poczucia sensu życia”

$1 \mathrm{~W}$ artykule komunikuję jedynie fragment wyników szerszego przedsięwzięcia badawczego dotyczącego tej problematyki. 
(Theiss 2012, s. 15). Im liczniejsze i większe są zagrożenia społeczne, tym bardziej obowiązująca staje się troska o ludzi zarówno zagrożonych, jak i zagrażających sobie bądź innym.

Jak istotne to zagadnienie i jakie należy przypisać mu znaczenie, ukazują choćby przysłowia stanowiące skarbnicę wiedzy o ludzkiej naturze oraz prawidłowościach zachowania człowieka. Jedno z nich: „Troska dzienna - noc bezsenna” (Nyczaj, red., 1994, s. 229) ujawnia prawdę o wrażliwości emocjonalnej i moralnej człowieka, który pogrąża się w troskach, mając ku temu powód; przysłowie zawiera również ostrzeżenie, iż jeśli zatroskany człowiek nie rozwiąże problemów właściwie, troski dnia powszedniego nie miną samoczynnie.

Człowiek w toku rozwoju filo- i ontogenetycznego doskonalił umiejętność przejawiania troski o siebie i innych. Dzięki m.in. aktom troski zaktywizował emocje i uczucia pozytywne, takie jak: empatia, życzliwość, sympatia, czułość, szczodrość, jednocześnie minimalizując emocje i uczucia negatywne, np. złość, gniew, wrogość, zawiść itp.

Za pośrednictwem troski o innych ludzi podmiot troszczący się zyskuje gratyfikacje psychologiczne (właściwą samoocenę wynikającą m.in. z poczucia sprawstwa, kompetencji; zaspokojenie potrzeb psychicznych i duchowych; pozytywny obraz świata) oraz tworzy dogodne warunki dla swego rozwoju moralnego. Natomiast podmiot podlegający trosce zyskuje konstruktywne doświadczenie emocjonalne, na podstawie którego buduje pozytywny obraz siebie, innych ludzi i świata. Zaspokaja również swe potrzeby fizyczne bądź psychiczne. Wzmocnienie sfery duchowej, emocjonalno-uczuciowej, motywacyjnej i pośrednio również intelektualnej odbiorcy przejawów troski stanowi rezultat troskliwego zajmowania się drugim człowiekiem. Mimo asymetryczności relacji (nierówności wkładów i zysków psychologicznych) więź emocjonalna między troszczącym się i doświadczającym troski pozwala zrealizować jej profilaktyczne lub terapeutyczne funkcje.

Zauważone deficyty rozwoju, niezaspokojone potrzeby, bezradność, choroba stają się motywami troski (troszczenia się bądź zatroszczenia się), wyrażonej w postaci działań edukacyjnych, opiekuńczych i leczniczych. Działania te w dziejach ludzkości, np. utworzenie instytucji użyteczności publicznej, pozwoliły na sprawniejsze świadczenie pomocy jednostkom, grupom i społecznościom najbardziej jej potrzebującym - poszkodowanym wskutek wojny czy kataklizmu. Aktywność humanitarna (jakąkolwiek opatrzy się ją nazwą: altruizmu, filantropii, dobroczynności, wielkoduszności, wolontariatu, społecznikostwa) stanowi jeden z najistotniejszych czynników rozwoju człowieka oraz postępu społecznego i kulturowego. Człowiek troszczący się o kogoś intensyfikuje swe poczucie sensu życia, troskę można zatem uznać za czynnik noetyczny oraz istotny komponent dobrego życia, tzn. subiektywnie i obiektywnie wartościowego, a zarazem satysfakcjonującego. 


\section{O trosce - interdyscyplinarnie}

Warto przeanalizować, jak zagadnienie troski jest eksploatowane w innych dziedzinach nauki, choćby filozofii (zwłaszcza teorii wartości etycznych), psychologii, medycynie, politologii, teologii.

Filozofowie w dyskusjach etycznych i rozważaniach nad moralnością odsyłają rozmówców najczęściej do poglądów Konfucjusza, Martina Heideggera (w egzystencjalnym opisie jestestwa wyróżnił on trzy komponenty: troskę, trwogę i bycie-ku-śmierci. Troska dotyczy głównie rozwoju bycia sobą i bojaźni przed uchybieniem w byciu sobą; troskliwość odnosi się do innych współjestestw, natomiast zatroskanie - do rzeczy) (Heidegger 1994), Miltona Mayeroffiego (personalistyczna troska stanowi dynamiczną relację nadającą ludzkiemu życiu sens i wspierającą rozwój, ale również pociągającą za sobą pewne powinności) (Mayeroff 1971), Emmanuela Lévinasa (społeczna relacja troski stanowi wezwanie do dobroci, zaś otwarcie się na drugiego człowieka wyraża się przede wszystkim w trosce o jego potrzeby; koncepcja troski tego filozofa inspiruje zwłaszcza przedstawicieli nauk medycznych do budowania medycznej etyki troski) (Lévinas 2002) czy Virginii Held (ujmuje troskę zarówno jako mentalne nastawienie, jak i działanie - przejaw aktywności; wykracza poza pierwotne pojmowanie troski - o dziecko - w kontakcie macierzyńskim - oraz proponuje objąć pojęciem troski również inne relacje rodzinne, relacje przyjacielskie i zawodowe) (Held 2006). Istotne rozróżnienie między troską a współczuciem czy litością zaakcentował filozof polski Stefan Symotiuk (Symotiuk 2011). W dziedzinie etyki na uwagę zasługuje również klasyczne postrzeganie troski przez Andrzeja Waleszczyńskiego (Waleszczyński 2012).

Psycholodzy, zwłaszcza przedstawiciele psychologii rozwojowej, społecznej i wychowawczej, charakteryzują troskę jako emocję, uczucie, stan, relację wymagającą zaangażowania emocjonalnego, oraz postawę, zwracając uwagę nie tylko na troskę o innych ludzi, lecz także o siebie. „Empatyczna troska” (Davis 1999, s. 140) stanowi podstawowy termin psychologii komunikacji oraz warunek prawidłowo przeprowadzonej i skutecznej psychoterapii.

W politologii wiąże się kategorię troski ze sferą prywatną i publiczną (zob. Sepczyńska 2012; por. Fajgielski, Potakowski, red. 2013), charakteryzuje jej rozwój historyczny (od relacji mikrospołecznych - matriarchalnych, do makrospołecznych) oraz funkcje w polityce państw (m.in.: uspołecznienia, indywidualizacji, budowania demokracji opierającej się na pluralizmie, korzystaniu z uprawnień i przestrzeganiu obowiązków obywatelskich).

W medycynie naukowcy poddają analizie troskę jako zasadę postępowania (zob. Beauchamp, Childress 1996), wymaganą dyspozycję i postawę lekarza lub pielęgniarki wobec pacjenta. Podkreślają swoistość troskliwości personelu medycznego w porównaniu $\mathrm{z}$ troską przejawianą w innych dziedzinach społecznych. Uzasadniają troskę i troskliwość poszanowaniem świętości życia i supererogacją (zob. Dobrowolska 2010). 
Z kolei teolodzy posługują się pojęciem troski w deskrypcji troskliwości jako cechy Boga Ojca, innych osób świętych oraz Kościoła. Świadectwem takiego ujmowania troski są m.in. encykliki (por. Jan Paweł II 2008) i prace zbiorowe (por. Offmański, red., 2008; por. Kukołowicz, red., 1992; por. Mazur, red., 2012).

Przedstawiciele wyliczonych nauk ujawniają powiązania troski $\mathrm{z}$ innymi jakościami aksjologii, a mianowicie: miłością (Orzelska 2014); odpowiedzialnością (Wojtyła 1960); bliskością uczuciową (Żywczok 2013); dobrem (Wajsprych 2011) i dobroczynnością; odwagą (Kicowska, Kwieciński, red., 2005); nadzieją (Murawska 2011; Theiss 2012); sprawiedliwością (Held 1995; Czyżowska 2012); pokojem (Sepczyńska 2012); empatią (Davis 1999); mądrością (Dyrda, oprac., 2010); autentycznością (Heidegger 1994); życzliwością (Sepczyńska 2012); prawdą (Gadow²: za Dobrowolska 2010, s. 144; por. Żywczok 2016); wyrozumiałością (Kwieciński 2012); wspaniałomyślnością (Żywczok 2011); altruizmem (Łobocki 2002).

\section{Troska, troszczenie się, zatroszczenie się, zatroskanie, troskliwość - wyjaśnienia leksykalne}

W języku polskim treść pojęcia troski odnosi się po pierwsze - do uczucia niepokoju wywołanego trudną sytuacją lub jej przewidywaniem, np. troska/i bezustanna/e, głęboka/e, ciężka/e, matczyna/e, codzienna/e, materialne (być wolnym od trosk; żyć bez trosk; nie mieć trosk; nie zaznać trosk; przyczyniać komuś wiele trosk); po drugie - do dbałości o coś, zabiegania o coś; troszczenia się, np. troska o rodzinę, pacjenta, dobro pracowników, byt, przyszłość, język (otoczyć kogoś troską; coś jest przedmiotem czyjejś troski; czynić coś $\mathrm{w}$ trosce o kogoś). Z kolei termin zbliżony do poprzedniego semantycznie - „zatroskanie” - oznacza: troskę; niepokój o kogoś, o coś; strapienie, np. „na jego twarzy było widać zatroskanie”) (Szymczak, red. 1993, s. 534, 969). Synonimami troski są również: 1) niepokój; 2) kłopot, zmartwienie, zgryzota, frasunek, utrapienie, strapienie, bieda; 3) dbałość o kogoś, zabiegi o coś (zabieganie o coś) (Cienkowski 1993, s. 268).

Czynność - „troszczenie się”, pochodząca od „troskać się” (starsza forma, np. „troskała się jego chorobą"), a aktualnie używana jako „troszczyć się”, oznacza przejawianie troski, bycie przejętym troską, dbanie o kogoś, o coś; kłopotanie się, niepokojenie się, myślenie o kimś, o czymś z troską, martwienie się (np.: „nie troszcz się o mnie"; troszczyć się o starych rodziców; troszczyć się o przyszłość córki/syna) (Szymczak, red. 1993, s. 534). Synonimami „troszczenia się” bądź „troskania się”

2 Relacja troski nie byłaby pełna bez uwzględnienia takich elementów komunikowania się podmiotów, jak mówienie prawdy. Zwraca na to uwagę Sally Gadow, jedna z teoretyczek pielegniarstwa. Przez prawdomówność pielęgniarka i lekarz pomagają pacjentowi poznać to, co subiektywnie przeżywa on w związku z chorobą, oraz to, co jest z nią obiektywnie związane. Na tej podstawie pacjent może dokonywać świadomych wyborów, okiełznać strach przed nieznanym i zachować poczucie godności. 
są: opiekować się kimś, czymś; dbać o kogoś lub o coś; niepokoić się, martwić się o kogoś, o coś; mieć w swojej pieczy, mieć pod opieką; otaczać opieką, staraniem (Cienkowski 1993, s. 268). Formą zbliżoną do „troszczyć się” jest „zatroszczyć się”, czyli zadbać o kogoś, o coś; zaopiekować się; zająć się; wykazać troskę o kogoś, o coś; pomyśleć o kimś, o czymś, postarać się o coś, na przykład zatroszczyć się o przyjaciela; zatroszczyć się o czyjąś przyszłość (Szymczak, red. 1993, s. 969; Cienkowski 1993, s. 338).

Troskliwość to troska okazywana komuś, dbałość o kogoś, opiekowanie się kimś bądź czymś; pieczołowitość, staranność, np. troskliwość matczyna, kobieca, ojcowska, zbyteczna, nadmierna (odnosić się do kogoś ze szczególną troskliwością; okazywać troskliwość żonie). Zatem człowiek troskliwy to ktoś okazujący dbałość o kogoś, o coś, troszczący się; będący wyrazem czyjejś troski, dbałości; pieczołowity, staranny, np. troskliwa matka, opieka; troskliwy wzrok (Szymczak, red. 1993, s. 534). Synonimami troskliwości są: 1) zapobiegliwy, pieczołowity, dbały; 2) staranny, pilny, dokładny; sumienny (Cienkowski 1993, s. 268). Troskliwość stanowi zatem cnotę moralną i cechę charakteru (zaletę) człowieka troskliwie traktującego innych ludzi, np. pielęgnować troskliwie chorego; okrywać troskliwie dziecko; dbać troskliwie o ogród (Szymczak, red. 1993, s. 534). Natomiast człowiek zatroskany to osoba: 1) przejęta troską o kogoś, o coś; zaniepokojona, np. zatroskana matka (chodził wiecznie zatroskany); 2) będąca wyrazem, objawem troski, zmartwienia, np. zatroskana mina; zatroskane spojrzenie (tamże, s. 969).

Uogólniając analizy dotyczące treści i zakresu pojęć („troska”, „zatroskanie”, „troszczenie się”, „zatroszczenie się”, „troskliwość”), można stwierdzić, iż różnice leksykalne między nimi są nieznaczne. Warto więc w celu lepszego zrozumienia i uporządkowania terminów - jakże istotnych w pedagogice - wypowiedzieć się również na temat podobieństw i różnic semantycznych.

Troska bądź zatroskanie (różniące się od troski obecnością niepokoju, a nawet smutku) stanowią raczej nastawienia mentalne podmiotu niż czyny. Zatroszczenie się jest już przejawem aktywności człowieka - celowym i na ogół ukierunkowanym działaniem, i raczej aktem niż procesem; nie bez powodu kojarzy się raczej z zainicjowaniem działań niż z działalnością długotrwałą. Z kolei troszczenie się można uznać już nie tylko za czynność, lecz także za postawę, i raczej proces niż wyłącznie akt. Natomiast troskliwość, zaliczona już w starożytności do cnót moralnych, jest także pozytywną cechą/dyspozycją ludzkiego charakteru/osobowości (zaletą) i z pewnością wyróżnikiem człowieka, choć troski utożsamionej z opieką nad potomstwem trudno nie przypisać również niektórym zwierzętom.

\section{Wychowawcze kształtowanie człowieka troskliwego}

W niniejszym artykule zostało już zasygnalizowane, że troska stanowi nastawienie społeczno-emocjonalne, relację społeczną i opiekuńczą, reakcję na niezaspokojone potrzeby własne bądź innych ludzi, motyw działań, działanie (troszczenie się, 
zatroszczenie się) bądź działalność, powinność, obowiązek i zobowiązanie, akt i proces, wartość, cnotę moralną, cechę charakteru bądź osobowości, cel wychowania oraz składnik ideału wychowania. Warto więc ukazać, jak przebiega wychowawcze kształtowanie człowieka troskliwego, który jest zarazem podmiotowym rezultatem oddziaływań wychowawczych. Interioryzacja troski i troskliwości wśród wychowanków stanowi istotne zadanie rodziców i wychowawców, oraz proces realizowany etapowo - od okresu prenatalnego aż do ukształtowania się określonej postawy i stylu życia.

W biologiczne zadatki (i zdolności) do przejawiania troski są wyposażeni wszyscy ludzie, jednak nie wszyscy w toku procesu socjalizacji i wychowania rozwijają swe zadatki czy doskonalą zdolności. Jednym z pierwszych doświadczeń emocjonalnych, jakie nabywa dziecko już od okresu prenatalnego, jest doświadczenie troszczenia się o nie przez matkę (pozostającą początkowo z dzieckiem w łączności fizycznej i psychicznej) oraz otoczenie społeczne, zwłaszcza członków rodziny. W trakcie kolejnych okresów rozwoju (np. noworodkowego, niemowlęcego, poniemowlęcego, przedszkolnego, szkolnego) dziecko nabiera poczucia i przekonania, że inni ludzie troszczą się o nie, a jednocześnie przejmuje/naśladuje określony styl troszczenia się o innych, stając się coraz bardziej skłonne samodzielnie przejawiać troskę o otoczenie.

To wczesnodziecięce doświadczanie troski innych ludzi predysponuje i motywuje do wzorowania się (dzięki wzorcom, wzorom, autorytetom) i identyfikacji ze wzorcem/wzorem/autorytetem, czyli do podobnego troszczenia się o kogoś lub o coś. Czynność troszczenia się o innych, której rodzice bądź wychowawcy chcą w procesie wychowania nauczyć dzieci bądź wychowanków, wymaga trenowania (ćwiczenia), tzn. licznych powtórzeń w zakresie obejmowania troską innych. Nie bez znaczenia jest naturalnie to, czy przekazujemy wzorzec troski o siebie, innych ludzi (np. rodzinę; dzieci przebywające w placówkach opiekuńczych, leczniczych), o zwierzęta (np. w schronisku dla zwierząt) czy rzeczy (np. o pamiątki rodzinne, dzieła kultury).

Przywoływanie wzorów osobowych za pośrednictwem zapoznania (wychowanków, uczniów, podopiecznych) z biografiami ludzi troszczących się o innych okazuje się zarazem stosowaniem najistotniejszej w pedagogice - metody modelowania (inaczej - osobistego wpływu wychowawcy). Zastosowanie mogą znaleźć w tym wypadku wzory osobowe, choćby Matki Teresy z Kalkuty, Brata Alberta Chmielowskiego, Urszuli Ledóchowskiej, Edyty Stein, Ojca Maksymiliana Kolbe, Siostry Małgorzaty Chmielewskiej, Alberta Schweitzera, Weroniki i Grzegorza Dowlaszów, małżeństwa prowadzącego przez kilkadziesiąt lat rodzinny dom dziecka, schronienie dla ponad setki dzieci pochodzących $\mathrm{z}$ rodzin niewydolnych wychowawczo. Ta gigantyczna 350-osobowa rodzina ze Szczecina została również uwieczniona w biografii matki napisanej przez jedną z córek - Inkę (Dąbrowska 2003). Analiza powyższych wzorów osobowych prowadzi do wniosku, iż najistotniejsze w kształtowaniu w wychowankach troskliwości okazuje się okazywanie im 
wyrozumiałości, dające im poczucie wolności wyboru i wyposażające ich w pragnienie odwzajemnienia otrzymywanej troski. Analizując biografie ludzi troskliwych, warto skorzystać jednocześnie z metody nadawania znaczenia (sytuacjom, zdarzeniom i relacjom, w których wymagane okazują się troska i troskliwość) oraz funkcji regulatywnej (ukierunkowanie postępowania) normie moralnej nakazu: „troszcz się o innych ludzi i siebie”, istotnego komponentu przykazania miłości bliźniego.

Systematyczne powtarzanie czynności troszczenia się/zatroszczenia się sprzyja nabywaniu umiejętności troszczenia się o kogoś/o coś. Doskonaląc tę cenną umiejętność, podmiot troszczący się kształtuje w sobie taką dyspozycję/cechę charakteru/osobowości, jak troskliwość (będąca również cnotą moralną). Czynnikami sprzyjającymi utrwaleniu tej dyspozycji są m.in. sytuacja wychowawcza, zaaranżowana lub spontaniczna, wymagająca przejawiania troski, oraz pozytywna atmosfera/klimat wychowania. Analizowana dyspozycja stanowi następnie istotny składnik postawy opiekuńczej. Postawę troski, nie tylko o ludzi, zwierzęta, rośliny i rzeczy z najbliższego otoczenia, lecz także postawę uogólnionej troski o świat czy ludzkość można uznać już za podwalinę wytworzenia się określonego stylu życia (np. altruistycznego lub supererogacyjnego). Tendencja do troszczenia się, czyli otaczania troską kogoś/czegoś, charakteryzuje się czynieniem tego prawidłowo, chętnie i względnie skutecznie.

Zaprezentowane porównanie powinno skłaniać do namysłu nad pojęciami troski, zatroskania, troszczenia się/zatroszczenia się, troskliwości, ujmowanymi jako podstawowe, jednak nietożsame kategorie pedagogiczne (korzystając z kryteriów obowiązujących zwłaszcza w pedagogice ogólnej i teorii wychowania). Mam nadzieję, że forma komparatystycznego zobrazowania zawartości merytorycznej (tabela 1) okaże się pomocna w uporządkowaniu oraz uprzystępnieniu wiedzy dotyczącej kształtowania człowieka troskliwego w procesie wychowania.

Tabela 1. Troska i terminy bliskoznaczne - porównanie (przyjęto kryteria stosowane w pedagogice ogólnej i teorii wychowania)

\begin{tabular}{|l|c|c|c|c|l|}
\hline $\begin{array}{c}\text { Podstawowe } \\
\text { kryteria }\end{array}$ & Troska & Zatroskanie & $\begin{array}{c}\text { Troszczenie } \\
\text { się }\end{array}$ & $\begin{array}{c}\text { Zatroszczenie } \\
\text { się }\end{array}$ & Troskliwość \\
\hline Akt & & + & & + & \\
\hline Proces & & & + & & \\
\hline Zadatek & + & + & + & + & \\
\hline Zdolność & & & + & + & \\
\hline Umiejętność & & & + & + & \\
\hline
\end{tabular}




\begin{tabular}{|c|c|c|c|c|c|}
\hline $\begin{array}{c}\text { Podstawowe } \\
\text { kryteria }\end{array}$ & Troska & Zatroskanie & $\begin{array}{c}\text { Troszczenie } \\
\text { się }\end{array}$ & $\begin{array}{c}\text { Zatroszczenie } \\
\text { się }\end{array}$ & Troskliwość \\
\hline Czynność & & & + & + & \\
\hline Czyn & & & + & + & \\
\hline $\begin{array}{l}\text { Działanie/ } \\
\text { działalność }\end{array}$ & & & + & + & \\
\hline $\begin{array}{l}\text { Cnota } \\
\text { moralna }\end{array}$ & & & & & + \\
\hline $\begin{array}{l}\text { Dyspozycja/ } \\
\text { cecha cha- } \\
\text { rakteru/ } \\
\text { osobowości }\end{array}$ & & & & & + \\
\hline $\begin{array}{l}\text { Emocja/ } \\
\text { uczucie/stan } \\
\text { emocjonalny }\end{array}$ & + & + & & & \\
\hline $\begin{array}{l}\text { Postawa } \\
\text { opiekuńcza }\end{array}$ & + & + & + & + & + \\
\hline Styl życia & + & + & + & + & + \\
\hline $\begin{array}{l}\text { Wartość } \\
\text { (moralna) }\end{array}$ & + & & & & \\
\hline Wzorzec & + & + & + & + & + \\
\hline Wzór osobowy & + & + & + & + & + \\
\hline $\begin{array}{l}\text { Cel } \\
\text { wychowania }\end{array}$ & & & + & + & + \\
\hline $\begin{array}{l}\text { Norma } \\
\text { moralna }\end{array}$ & + & & + & + & \\
\hline $\begin{array}{l}\text { Zasada } \\
\text { wychowania }\end{array}$ & & & + & + & \\
\hline $\begin{array}{l}\text { Komponent } \\
\text { ideału } \\
\text { wychowania }\end{array}$ & & & & & + \\
\hline $\begin{array}{l}\text { Sytuacja } \\
\text { wychowawcza/ } \\
\text { składnik } \\
\text { sytuacji } \\
\text { wychowawczej }\end{array}$ & & & + & + & \\
\hline
\end{tabular}




\begin{tabular}{|l|c|l|c|c|c|}
\hline \multicolumn{1}{|c|}{$\begin{array}{c}\text { Podstawowe } \\
\text { kryteria }\end{array}$} & Troska & Zatroskanie & $\begin{array}{c}\text { Troszczenie } \\
\text { się }\end{array}$ & $\begin{array}{c}\text { Zatroszczenie } \\
\text { się }\end{array}$ & Troskliwość \\
\hline $\begin{array}{l}\text { Atmosfera } \\
\text { wychowania/ } \\
\text { składnik } \\
\text { atmosfery } \\
\text { wychowania }\end{array}$ & + & & + & + & + \\
\hline Powinność & + & & + & + & + \\
\hline $\begin{array}{l}\text { Relacja } \\
\text { społeczna/ } \\
\text { opiekuńcza }\end{array}$ & & & + & + & + \\
\hline Kompetencja & & & + & + & \\
\hline $\begin{array}{l}\text { Element } \\
\text { kwalifikacji } \\
\text { zawodowych }\end{array}$ & & & & & + \\
\hline
\end{tabular}

Źródło: opracowanie autorskie Alicji Żywczok.

Intrygujące wydaje się także rozgraniczenie między opieką, pomocą, wsparciem a troską. „Troska” i „zatroskanie” stanowią raczej nastawienie mentalne podmiotu niż określone działanie, choć „troszczenie się” czy „zatroszczenie się” odnoszą się do ludzkich działań. Z kolei „troskliwość” należy do cech/dyspozycji opiekuńczych i również nie jest równoznaczna z działaniem, chociaż je zapowiada. „Opieka”, „pomoc” i „wsparcie” raczej nie kojarzą się z nastawieniem mentalnym, ale z czynnościami/działaniami człowieka. Troska, silniej niż w przypadku opieki, pomocy czy wsparcia, wypływa z ludzkiego zaangażowania emocjonalnego i uczuciowości wyższej. W ramach aktywności zawodowej ktoś raczej opiekuje się kimś bądź udziela komuś pomocy i wsparcia, niż troszczy się o kogoś. Sprawuje się opiekę, udziela pomocy i wsparcia często w ramach realizacji formalnych zadań zawodowych, np. kurateli sądowej. Troska częściej stanowi rezultat więzi emocjonalnej (choćby rodzicielskiej czy rodzeństwa) między podmiotami: troszczącym się i podlegającym trosce. A ponadto troska stanowi postawę skierowaną nie jedynie na dany podmiot, ale uogólnioną także na świat/kosmos. Rozpatrywanie pojęć opieki, pomocy i wsparcia w tak szerokim kontekście wydawałoby się niedorzeczne, natomiast pojęć troski o świat/kosmos czy ludzkość - uzasadnione i bardzo wskazane.

\section{Podsumowanie}

Analizy dotyczące treści i zakresu pojęć (troska, zatroskanie, troszczenie się, zatroszczenie się, troskliwość) pozwalają na stwierdzenie, iż różnice leksykalne i semantyczne między nimi są nieznaczne. Troska bądź zatroskanie (różniące 
się od troski obecnością niepokoju, a nawet smutku) stanowią raczej nastawienie mentalne podmiotu niż czyn. Zatroszczenie się jest już przejawem aktywności człowieka - celowym i na ogół ukierunkowanym działaniem, i raczej aktem niż procesem; nie bez powodu kojarzy się raczej z zainicjowaniem działań niż z działalnością długotrwałą. Z kolei troszczenie się można uznać nie tylko za czynność, lecz także za postawę, i raczej proces niż akt. Natomiast troskliwość, zaliczona już w starożytności do cnót moralnych, jest także pozytywną cechą/dyspozycją ludzkiego charakteru/osobowości (zaletą), i z pewnością wyróżnikiem człowieka, choć troski utożsamionej z opieką nad potomstwem trudno nie przypisać również niektórym zwierzętom.

Troska o kogoś lub o coś chroni człowieka przed zagrożeniami, przyczyniła się i wciąż przyczynia się do jego przetrwania oraz nabywania dóbr niezbędnych do życia, dynamizuje ludzkie działanie oraz emocje/uczucia pozytywne (rugując bądź minimalizując negatywne), rodzi w troszczącym się i odbiorcy troski poczucie sensu życia. Za pośrednictwem troski, a zwłaszcza czynności troszczenia się (i zatroszczenia się) o innych, człowiek rozwija się pod względem emocjonalnym, uczuciowym, społecznym, moralnym, duchowym. Troska (i analizowane terminy bliskoznaczne) stanowią zatem istotne czynniki w rozwoju człowieczeństwa, postępie społecznym (w tym socjalnym) i kulturowym. Troskę mającą swe powiązanie Z wieloma innymi wartościami (miłością, odpowiedzialnością, bliskością uczuciową, dobrem, odwagą, nadzieją, sprawiedliwością, pokojem, empatią, mądrością, autentycznością, życzliwością, prawdą, wyrozumiałością, wspaniałomyślnością, altruizmem) można uznać również za komponent dobrego życia.

Kategoria troski, choć interdyscyplinarna (obecna m.in. w filozofii, psychologii, medycynie, politologii, teologii), ma szczególne znaczenie w pedagogice, jako nauce o wychowaniu, ze względu na fakt/konieczność wychowywania potomstwa i sprawowania nad nim opieki. W pedagogice problematyka troski rzadko była poddawana eksploracji; w jej subdyscyplinach upowszechniły się raczej inne terminy, takie jak: opieka, pomoc, wsparcie, wspomaganie. Warto zatem docenić to pojęcie, czyniąc je przedmiotem badań również historii wychowania czy etyki pedagogicznej. Pedagodzy teoretycy i praktycy mogą z powodzeniem skorzystać z ujmowania troski także jako relacji społecznej i opiekuńczej (nie tylko macierzyńskiej), reakcji na niezaspokojone potrzeby własne bądź innych ludzi, motyw działań, obowiązek i zobowiązanie, cel wychowania, składnik ideału, sytuacji i atmosfery wychowania oraz kompetencję i przejaw profesjonalizmu.

\section{Bibliografia}

Beauchamp T. L., Childress J. F. (1996). Zasadyetyki medycznej, tłum. W. Jacórzyński. Warszawa: „Książka i Wiedza”.

Cienkowski W. (1993). Praktyczny słownik wyrazów bliskoznacznych. Warszawa: Polska Oficyna Wydawnicza „BGW”. 
Czyżowska D. (2012). Sprawiedliwość i troska. O sposobach rozwiązywania dylematów moralnych przez kobiety i mężczyzn. Kraków: Wydawnictwo Uniwersytetu Jagiellońskiego.

Davis M. H. (1999). Empatia. O umiejętności współodczuwania, tłum. J. Kubiak. Gdańsk: Gdańskie Wydawnictwo Psychologiczne.

Dąbrowska Z. (2003). Weronika Dowlasz - jedyna w Polsce taka matka. „Małżeństwo i Rodzina", nr 1, s. 56-59.

Dobrowolska B. (2010). Wprowadzenie do medycznej etyki troski. Bydgoszcz: Oficyna Wydawnicza Branta.

Dyrda H. (oprac.). (2010). Mądrość i troska. Wspomnienia o Ojcu prof. Mieczysławie Albercie Krąpcu OP. Mikołów: Wydawca PW „Tolek”.

Fajgielski P., Potakowski P. (red.). (2013). Domena publiczna - troska o prawa podstawowe? Lublin: Wydawnictwo Katolickiego Uniwersytetu Lubelskiego.

Heidegger M. (1994). Bycie i czas, tłum. B. Baran. Warszawa: Państwowe Wydawnictwo Naukowe.

Held V. (1995). The Meshing of Care and Justice. Colorado: Westview Press.

Held V. (2006). The Ethics of Care: Personal, Political and Global. Oxford, New York: Oxford University Press.

Jan Paweł II (2008). Solicitudo rei socialis = Troska o sprawy społeczne. Encyklika Ojca Świętego Jana Pawła II skierowana do biskupów, kapłanów, rodzin zakonnych, synów i córek Kościoła oraz wszystkich ludzi dobrej woli z okazji dwudziestej rocznicy ogłoszenia Populorum Progressio. Warszawa: Katolicka Agencja Informacyjna, Hachette Livre Polska.

Kicowska A., Kwieciński Z. (red.). (2005). Dzielność i troska - studia dedykowane Profesor Eugenii Malewskiej. Olsztyn: Wydawnictwo Uniwersytetu Warmińsko-Mazurskiego.

Kukołowicz T. (red.). (1992). Troska Kościoła o rodzinę w Polsce. Warszawa, Wydawnictwo „Pallottinum”.

Kwieciński Z. (2012). Zmienić kształcenie nauczycieli. W: tenże: Pedagogie postu. Preteksty, konteksty, podteksty. Kraków: Oficyna Wydawnicza „Impuls”.

Lévinas E. (2002). Całość i nieskończoność. Esej o zewnętrzności, tłum. M. Kowalska. Warszawa: Państwowe Wydawnictwo Naukowe.

Łobocki M. (2002). Altruizm a wychowanie. Lublin: Wydawnictwo Uniwersytetu Marii Curie-Skłodowskiej.

Mayeroff M. (1971). On Caring. New York: Harper \& Row.

Mazur J. (red.). (2012). Rozwój i dobro wspólne - dyskurs w 25-lecie encykliki „Solicitudo rei socialis” Jana Pawła II. Kraków: Wydawnictwo Naukowe Uniwersytetu Papieskiego Jana Pawła II.

Murawska A. (2011). Edukacja jako troska o nadzieję człowieka. Szczecin: Wydawnictwo Naukowe US.

Nyczaj S. (red.). (1994). Mała księga przysłów polskich. Radom: Oficyna Wydawnicza „Ston I”. 
Offmański A. (red.). (2008). Troska Kościoła o współczesną polską młodzież-zarys problematyki. Szczecin: Wydawnictwo Wydziału Teologicznego US.

Orzelska J. (2014). W stronę pedagogiki istotnej egzystencjalnie. Kraków: Oficyna Wydawnicza „Impuls”.

Sepczyńska D. (2012). Etyka troski jako filozofia polityki. „Etyka”, nr 45, s. 37-61.

Symotiuk S. (2011). Troska czy litość. W: Sośnicka J., Dobrołowicz J. (red.). Troska o Innego. Szkice humanistyczne. Kielce: Wydawnictwo Kieleckiego Towarzystwa Naukowego.

Szmaus-Jackowska A. (2011). Troska o siebie osób w starszym wieku. Bydgoszcz: Wydawnictwo Uniwersytetu Kazimierza Wielkiego.

Szymczak M. (red.). (1993). Słownik języka polskiego. T. 3. Warszawa: Wydawnictwo Naukowe PWN.

Theiss W. (2012). Troska i nadzieja. Działalność społeczno-wychowawcza ks. Henryka Szumana na Pomorzu w latach 1908-1939. Toruń: Wydawnictwo Adam Marszałek.

Waleszczyński A. (2012). Pojęcie troski we współczesnej etyce. „Studia Philosophiae Christianae", nr 2, s. 143-157.

Wojtyła K. (1960). Miłość i odpowiedzialność. Studium etyczne. Lublin: Wydawnictwo Towarzystwa Naukowego Katolickiego Uniwersytetu Lubelskiego.

Żywczok A. (2011). Inercja wspaniałomyślności w procesie wychowania dzieci i młodzieży a dezyderat komunikacyjnej asertywności. „Kwartalnik Pedagogiczny”, nr 3, s. 15-30.

Żywczok A. (2013). Hermeneutyka uczuciowej i duchowej bliskości. W: Żywczok A. (red.). Miłość - akt preferencji duchowości człowieka. Studium bliskości uczuciowej. Warszawa: Wydawnictwo Akademickie „Żak”.

Żywczok A. (2016). Wychować człowieka prawdomównego. Koncepcje, badania naukowe, wdrożenia. Katowice: Wydawnictwo Uniwersytetu Śląskiego.

\title{
CARE, CONCERN, THOUGHTFULNESS - NON-SPECIFIC RESEARCH SUBJECTS OF GENERAL PEDAGOGICS
}

\begin{abstract}
Referring to the current status of knowledge in the field of pedagogics and related sciences (especially philosophy, psychology, medicine, political sciences, theology), the author emphasizes the significance of interdisciplinary category of care (and semantically related terms such as "concern", "taking care", "consideration", "thoughtfulness") for the development of general pedagogics as a pedagogical sub-discipline. Apart from explaining the lexical differences and indicating differences between the aforementioned terms, the author also analyzes the scientific understanding of care (as, among others: a moral norm and obligation, social interaction, disposition, attitude) and the relationship between care and other moral qualities. The author also shows the conditions of the process of upbringing a thoughtful human being and stages of interiorization of the analyzed
\end{abstract}


quality. Hermeneutic methods seem justified in order to comprehensively cognize the quality of care.

Key words: care, concern, taking care, consideration, obligation, protective attitude, upbringing process, subject of research.

Alicja Żywczok - dr hab. nauk humanistycznych, pedagog i filozof. Pracuje na Wydziale Pedagogiki i Psychologii Uniwersytetu Śląskiego w Katowicach, w Instytucie Pedagogiki, w Zakładzie Teorii Wychowania. Zainteresowania badawcze: teoria wychowania, naukoznawstwo ogólne, antropologia filozoficzna, etyka pedagogiczna. Autorka 100 publikacji naukowych, w tym kilku monograficznych: Filozoficzne korzenie pedagogiki radości (Kraków 200o); Wychowanie do radości życia (Warszawa 2004); Aksjologia odkrycia naukowego studium rozwoju i wychowania osobowości naukowych (Toruń 2009); Ku afirmacji życia. Pedagogiczne podstawy pomyślnej egzystencji (Katowice 2011); Miłość - akt preferencji duchowości człowieka. Studium bliskości uczuciowej (red., Warszawa 2013); Znajomość, koleżeństwo, przyjaźn. Dynamizm ewoluowania więzi emocjonalnej (red., Warszawa 2014); Kierunki rozwoju etyki pedagogicznej i teorii wychowania moralnego (red. cz. monograficznej Chowanny, 2016, t. 1); Wychować człowieka prawdomównego. Koncepcje, badania naukowe, wdrożenia (Katowice 2016). Adres do korespondencji: ul. Michała Grażyńskiego 53, 40-126 Katowice. Adres e-mailowy: alicjazyw@wp.pl. 